\title{
Effects of Caulerpa lentillifera added into culture media on the growth and nutritional values of Phronima pacifica, a natural fish-feed crustacean
}

\author{
VIVI ENDAR HERAWATI ${ }^{1, \bullet}$, PINANDOYO ${ }^{1}$, RESTIANA WISNU ARIYATI ${ }^{1}$, NURMANITA RISMANINGSIH ${ }^{2}$, \\ SETO WINDARTO ${ }^{1}$, SLAMET BUDI PRAYITNO ${ }^{1}$, Y.S. DARMANTO ${ }^{3}$, OCKY KARNA RADJASA ${ }^{4}$ \\ ${ }^{1}$ Department of Aquaculture, Faculty of Fisheries and Marine Sciences, Universitas Diponegoro. J1. Prof. H. Soedarto, S.H., Semarang 50275, Central \\ Java, Indonesia. Tel./fax.: +62-24-7474698, `email: viviendar23@gmail.com \\ ${ }^{2}$ Department of Materials Chemistry, Graduate School of Engineering, Nagoya University. Furo-cho, Chikusa-ku, Nagoya 464-8603, Japan \\ ${ }^{3}$ Department of Fisheries Product Technology, Faculty of Fisheries and Marine Sciences, Universitas Diponegoro. J1. Prof. H. Soedarto, S.H., Semarang \\ 50275, Central Java, Indonesia \\ ${ }^{4}$ Department of Marine Science, Faculty of Fisheries and Marine Sciences, Universitas Diponegoro. J1. Prof. H. Soedarto, S.H., Semarang 50275, Central \\ Java, Indonesia
}

Manuscript received: 14 November 2020. Revision accepted: 28 December 2020

\begin{abstract}
Herawati VE, Pinandoyo, Ariyati RW, Rismaningsih N, Windarto S, Prayitno SB, Darmanto YS, Radjasa OK. 2021. Effects of Caulerpa lentillifera added into culture media on the growth and nutritional values of Phronima pacifica, a natural fish-feed crustacean Biodiversitas 22: 424-431. Phronima pacifica is a microcrustacean commonly used as natural feed in fish farming as it has high nutrient contents and is suitable based on larval fish mouth gap size and mass cultivation capacity. However, $P$. pacifica is not produced optimally and its supply is inadequate, so that $P$. pacifica culturing techniques need to be improved. The culture of $P$. pacifica is mostly done using sea grape seaweed (Caulerpa lentillifera). The aim of this study was to investigate the optimal stocking density of $C$. lentillifera added into media culture on the growth and nutritional values of $P$. pacifica. We applied a complete random design experiment with four treatments of stocking density of C. lentillifera (i.e., $0 \mathrm{~g} / \mathrm{m}^{2}$ (Control), $20 \mathrm{~g} / \mathrm{m}^{2}, 40 \mathrm{~g} / \mathrm{m}^{2}$, and $60 \mathrm{~g} / \mathrm{m}^{2}$ ) with 3 replicates for each treatment. The following parameters were analyzed, namely specific growth rate (SGR) of $C$. lentillifera, and the growth, biomass, growth rate, proximate analysis, and amino and fatty acid concentrations of $P$. pacifica. This study found that the addition of $C$. lentillifera into culture media significantly enhanced the growth of P. pacifica. The highest effect on the growth was observed in the treatment of $60 \mathrm{~g} / \mathrm{m}^{2}$ with $C$. lentillifera SGR value of $4.76 \pm 0.12 \% /$ day, and $P$. pacifica growth rate, population density and biomass of $4.41 \pm 0.12 \mathrm{ind} / \mathrm{day}, 53.81 \pm 8.79 \mathrm{ind} / \mathrm{L}$, and 1.14 $\pm 0.14 \mathrm{~g}$, respectively. Similarly, the highest protein and fat contained in P. pacifica was obtained in the treatment of $60 \mathrm{~g} / \mathrm{m}^{2}$ with $60.23 \%$ protein and $10.24 \%$ fat. Furthermore, the highest fatty acid profile was C20: $5 n-3$ of $13.23 \% \pm 0.08 \%$ and amino acid profile of $45.23 \% \pm$ $0.01 \%$. The application of the optimal stocking density of $C$. lentillifera in culture media could increase the growth and nutritional quality of $P$. pacifica which in turn could enhance aquaculture productivity.
\end{abstract}

Keywords: Caulerpa lentillifera, density, growth, nutritional quality, Phronima pacifica

\section{INTRODUCTION}

Amphipods serve as a natural source of feed for aquaculture activities (Rojano et al. 2014). Amphipods also have the potential to be used in integrated cultivation (IMTA) in ponds (Baeza-Rojano et al. 2013). Amphipod's shape is quite varied, there is no difference between the body size of marine and fresh amphipods. In some Amphipods, it has a thin, transparent cuticle and the muscles are weakly developed. Amphipods generally have slightly rounded bodies and are weak swimmers, being benthic-pelagic organisms. Some Amphipods have rather compact bodies with strong muscles and can swim very fast. Amphipods have a unique characteristic that is they can experience conglobation (rolling into a ball), which is turning their bodies round. The function of this conglobation is to protect itself from predators and to drown (Aoki et al. 2013). They are known as natural feed source applied in aquaculture activities (Baeza-Rojano et al. 2013) and has the potentials to be used in integrated aquaculture in ponds/fish cages (Jiménez-Prada et al 2018). Amphipoda has six sub-orders, namely
Pseudingolfiellidea, Hyperiidea, Colomastigidea, Hyperiopsidea, Senticaudata and Amphilochidea (Lowry and Myers 2017). One of the identified genera is Phronima spp. which belongs to Hyperiidea sub-order (Bishop and Geiger 2006).

Phronima pacifica is a species of Amphipoda microcrustacean that inhabits sea waters at a depth of 0-25 $\mathrm{m}$ below sea surface (Elder and Siebel 2015). P. pacifica has high nutrient contents, and it is commonly used to meet the nutrient requirements of brackish water fish larvae during the hatchery stage. In addition, the feed can fit through the mouth gaps of fish larvae, and it can be masscultivated (Herawati et al. 2014). P. pacifica is a nonselective filter feeder, therefore nutrients can be added through aquaculture media (Aoki et al. 2013).

In a food chain of aquaculture system, $P$. pacifica uses phytoplankton as one of the feeds in addition to bacteria and detritus in a culture media. As such, the type of culture media used greatly affects the nutritional quality of phytoplankton, bacteria and detritus which eventually affects the nutrient contents of $P$. pacifica (Damle and 
Chari 2011; Herawati et al. 2020). One of such culture media is sea grape (Caulerpa lentillifera).

$C$. lentillifera is a green seaweed of high economic value with the potential to drive development in the aquaculture industry. The entire $C$. lentillifera structure is a stem organ called a thallus. Thalli that die become detritus, which serve as feed for other organisms, so that seaweed provide habitat, shelter, spawning grounds, in addition, to feed that supports $P$. pacifica growth (Parker and Maria 2015). Nutrient concentrations in detritus affect the organic matter content in the culture media, and in turn the population density of $P$. pacifica as they can get the associated feed. The more sea grapes planted in a culture pond, the more $P$. pacifica individuals that will stick to the thalli.

However, to date, the optimal stocking density of $C$. lentillifera used as a culture medium in rearing $P$. pacifica is unknown. Previous study indicated that Phronima treated with fermented organic waste gave results with a peak population of 98 individuals / $\mathrm{L}$ that occurred on the $16^{\text {th }}$ day of aquaculture, and the highest biomass of $0.51 \mathrm{~g}$ (Herawati et al. 2020). The highest nutrient content was obtained at the highest protein proximate analysis value of $58.90 \%$, the proportion of the fatty acids comprised of eicosapentaenoic acid of $7.53 \%$, and lysine amino acids of 44.16 ppm.

Only few studies have explored sea grape cultivation to support $P$. pacifica growth. The purpose of the present study was to investigate the optimal stocking density of $C$. lentillifera for $P$. pacifica growth and nutritional quality. To achieve this aim, varying stocking densities of $C$. lentillifera were applied in culture media, then the following parameters were to be analyzed, namely specific growth rate (SGR) of $C$. lentillifera, and the growth, biomass, growth rate, proximate analysis, and amino and fatty acid concentrations of $P$. pacifica. The results of the present study could facilitate the development of the $P$. pacifica aquaculture industry.

\section{MATERIALS AND METHODS}

\section{Materials}

The materials for experiment in the present study were $2 \mathrm{~kg}$ of Caulerpa lentillifera seeds, and Phronima pacifica with stocking density of 3 ind/L. The materials were obtained from the Brackish Water Cultivation Aquaculture Fisheries Center (Balai Besar Perikanan Budidaya Air Payau), Jepara, Central Java, Indonesia.

\section{Experimental procedure}

Before culturing $P$. pacifica, $C$. lentillifera stocking was first carried out for 7 days so that the nutrients in the organic fertilizer would be absorbed by $C$. lentillifera. Subsequently, $P$. pacifica stocking was performed at a density of 3 ind/L. During the $P$. pacifica rearing, up to 60 $\mathrm{mL}$ of organic fertilizer (cow manure about $50 \mathrm{~g} /$ container that has been dried) was added every 3 days. The container used was made of fiber with a tank size of $60 \mathrm{~L}$, moreover, the water exchange was done every day.
The experimental design applied was a completely randomized design (CRD) with four treatments and three replicates for each treatment. The treatments were as follow: Treatment A (Control): $0 \mathrm{~g} / \mathrm{m}^{2} C$. lentillifera; Treatment B: $20 \mathrm{~g} / \mathrm{m}^{2}$ C. lentillifera; Treatment C: $40 \mathrm{~g} / \mathrm{m}^{2}$ C. lentillifera; and Treatment D: $60 \mathrm{~g} / \mathrm{m}^{2}$ C. lentillifera.

\section{Water quality parameters}

Water quality parameters, including temperature, dissolved oxygen (DO), salinity and $\mathrm{pH}$, were measured daily using a thermometer (Checktemp Digital Thermometer model HI98501, Hanna Instrument, Japan), a DO meter (AMTAST DO-820) and a pH meter (Jellas model PH-061), respectively. Water quality measurements were used to maintain $P$. pacifica individuals in stable condition. Water quality measurement data obtained are presented in ranges and compared with values in literature. The water quality data are presented in Table 1.

\section{Data collection}

Sampling for growth analyses was carried out every 2 days for $P$. pacifica and every 7 days for $C$. lentillifera up to 42 days of rearing. The analyses were performed at the exponential phase on the $10^{\text {th }}$ day during $P$. pacifica rearing. The analysis was performed at the exponential phase because $P$. pacifica has the highest nutritional quality during its growth, therefore, it is also the recommended time for harvesting. Moreover, Fogg (1965) stated that the highest nutritional quality of $P$. pacifica is in the exponential phase so it is suitable as natural feed given in aquaculture.

\section{Data analysis}

Growth rate of Phronima pacifica

Growth rate was calculated according to Krebs (1972) using the following formula:

$$
r=\frac{\ln N_{t}-\ln N_{0}}{t}
$$

Where: $r$ : growth rate (individuals/day); t: time required to achieve maximum growth (days); $\mathrm{N}_{\mathrm{t}}: P$. pacifica density on $\mathrm{t}$ day (individuals/L); $\mathrm{N}_{0}: P$. pacifica initial density (individuals/L).

Table 1. Water quality parameters

\begin{tabular}{lcc}
\hline \multicolumn{1}{c}{ Variables } & Value ranges & Reference values \\
\hline $\mathrm{DO}(\mathrm{mg} / \mathrm{L})$ & $3.5-4.5$ & $2.6-4.9^{*}$ \\
$\mathrm{pH}$ & 8 & $8-9^{*}$ \\
Temperature $\left({ }^{\circ} \mathrm{C}\right)$ & $28-30$ & $30-38^{*}$ \\
Salinity & 28 & $25-28^{* *}$ \\
Nitrite $(\mathrm{ppm})$ & $0.031-0.075$ & $0.056-1.329^{* *}$ \\
Nitrate $(\mathrm{ppm})$ & $0.008-0.440$ & $0.063-0.03^{* * *}$ \\
Phosphate & $0.135-1.605$ & $0.098-1.705^{* * *}$ \\
\hline
\end{tabular}

Note: *: Fattah et al. (2014); **: Fattah et al. (2019); ***: Azizah (2006) 
Population density of Phronima pacifica

Phronima pacifica was evaluated every 2 days. Since $P$. pacifica are attached to surfaces in clusters, sampling was carried out by stirring the culture media and then obtaining samples at the densest sampling points: front, middle, and back of the container as much as $1 \mathrm{~L}$ of water. The counting was done three times. After the evaluation was performed, the P. pacifica was put back in the container.

\section{Increase of biomass of Phronima pacifica}

Phronima pacifica biomass was determined by weighing at the beginning of stocking and weighing $P$. pacifica at the end of the rearing. The biomass weight was calculated by harvesting all $P$. pacifica using planktonets, then separating the water from the $P$. pacifica. Furthermore, the sample was weighed with an accuracy of 0.01 gram. The initial weight of $P$. pacifica was approximately 0.01 grams. The biomass was calculated using the formula presented by Krebs (1972):

$$
\mathrm{W}=\mathrm{W}_{\mathrm{t}}-\mathrm{W}_{0}
$$

Where: $\mathrm{W}$ : Increase in biomass $(\mathrm{g}) ; \mathrm{W}_{0}$ : Initial weight $(\mathrm{g}) ; \mathrm{W}_{\mathrm{t}}$ : Final weight $(\mathrm{g})$

\section{Proximate analysis}

The parameters used for proximate analysis were protein, fat, ash, crude fiber, and water. The analysis was performed once the sample is dried. The samples used for the analysis of amino acids and fatty acids were 10 grams of the dry weight each, and 20 grams of dry weight for proximate analysis. Lipid samples were analyzed using the gravimetric method using the weight of the sample to find the lipid levels. The proximate chemical composition of the samples was determined using a standard procedure (AOAC 2005; Herawati et al. 2017). Protein analysis was performed using the Kjeldahl method, while carbohydrate analysis was carried out manually based on the results of the proximate analysis.

\section{Essential amino acid profile}

The essential amino acid profile of $P$. pacifica was determined by examining its essential amino acid contents. Essential amino acid analysis was conducted using highperformance liquid chromatography (HPLC) type 1100 system with a Eurospher 100-5 C18, $250 \times 4.6 \mathrm{~mm}$ column with a P/N: 1115Y535 pre-column. The effluents were: A) $0.01 \mathrm{M}$ acetate buffer at pH 5.9; and B) $0.01 \mathrm{M} \mathrm{MeOH}$ acetate buffer at pH 5.9; THF> 80:15:5 $\Lambda$ Fluorescence: Ext: $340 \mathrm{~mm}$ Em: $450 \mathrm{~nm}$. About $2.5 \mathrm{~g}$ of sample was put into a sealed glass and $15 \mathrm{~mL} 6 \mathrm{M} \mathrm{HCl}$ was added. Subsequently, the mixture was vortexed for homogeneity and subjected to hydrolysis in an autoclave at $110^{\circ} \mathrm{C}$ for 12 $\mathrm{h}$, before being cooled to room temperature and neutralized with $6 \mathrm{M} \mathrm{NaOH}$. After the addition of $2.5 \mathrm{~mL} 40 \%$ lead acetate and $1 \mathrm{~mL} 15 \%$ oxalate acid, approximately $3 \mathrm{~mL}$ of the mixture was filtered with a $0.45 \mu \mathrm{m}$ Millex-HV filter (Merck KGaA, Darmstadt, Germany). Twenty-five microliters of the filtered mixture plus $475 \mu \mathrm{L}$ of OPA anhydrolase solution were vortexed and incubated for 3 min for injection into the HPLC system. Finally, $30 \mu \mathrm{L}$ of the final mixture was placed into the HPLC system. The amino acid composition of the sample was determined using a HPLC system (Shimadzu LC-6A, Shimadzu, Kyoto, Japan) (AOAC 2005; Herawati et al. 2017).

\section{Fatty acid profile}

The fatty acid profile of P. pacifica can be determined by analyzing its total fatty acid contents. The equipment used for the analysis was a QP-2010 Gas ChromatographMass Spectrophotometer (GCMS) (Shimadzu) and the Mass Spectrophotometer had a $50 \mathrm{~m}$ long, $0.22 \mathrm{~mm}$ diameter Wall Coat Open Tubular CP-SIL-88 column (Agilent, Santa Clara, CA, USA), with analysis performed at $120-200^{\circ} \mathrm{C}$ column temperature range. The method employed was in-situ transcertification. One-hundred milligram samples of $P$. pacifica were homogenized using $4 \mathrm{~mL}$ of water. The obtained $100 \mu \mathrm{L}$ homogenates were subsequently transferred into reaction tubes. One-hundred microliters of methylene chloride were then added, along with $1 \mathrm{~mL}$ of $0.5 \mathrm{M} \mathrm{NaOH}$ in methanol. Once nitrogen was added and the tubes sealed, they were heated to $90^{\circ} \mathrm{C}$ for 10 min. The reaction tubes were then cooled and $1 \mathrm{~mL} 14 \%$ $\mathrm{BF}_{3}$ in methanol added. After nitrogen addition, heating ensued at the same temperature for 10 minutes. Afterward, the reaction tubes were cooled to ambient temperature, and $1 \mathrm{~mL}$ of water and $200-500 \mu \mathrm{L}$ of hexane added. The mixtures were then vortexed for $1 \mathrm{~min}$ to extract the methyl ester of the fatty acid. After centrifuging, the upper layer of sample was ready for GC analysis. The fatty acid composition of the sample was determined using a gas chromatograph (Shimadzu) (AOAC 2005; Herawati et al. 2017).

\section{Statistical analysis}

Data obtained for $P$. pacifica included specific growth rate, relative growth rate, population density, and nutritional quality. The data were first tested for normality, homogeneity of variance and additivity. If the above assumptions were satisfied, one-way Analysis of Variance (ANOVA) was conducted to determine the effects of different sea grape stocking densities after 49 -d rearing on $P$. pacifica growth. If there were significant $(\mathrm{P}<0.05)$ or highly significant $(P<0.01)$ effects, the Duncan's Multiple Range Test (DMRT) was performed to determine differences between treatments, and to identify the optimal treatment.

\section{RESULTS AND DISCUSSION}

This study revealed that the density of $C$. lentillifera used in culturing activities affected the growth of $P$. pacifica based on the parameters of Specific Growth Rate (SGR) of $C$. lentillifera, and the growth rate, population density, biomass and nutritional quality of $P$. pacifica.

\section{Specific growth rate of Caulerpa lentillifera}

The result of Specific Growth Rates of C. lentillifera under various stocking densities is presented in Figure 1. 
The highest SGR of $C$. lentillifera was observed under the treatment of $60 \mathrm{~g} / \mathrm{m}^{2}$ at $4.76 \mathrm{ind} /$ day. According to the ANOVA results, the density $C$. lentillifera significantly influenced $P$. pacifica SGR $(\mathrm{P}<0.05)$. In addition, according to Duncan's Multiple Range test, SGR under the treatment of $0 \mathrm{~g} / \mathrm{m}^{2}$ was lower than those of 20,40 , and 60 $\mathrm{g} / \mathrm{m}^{2}$. The SGR under the $20 \mathrm{~g} / \mathrm{m}^{2}$ is significantly lower than the SGRs under the $40 \mathrm{~g} / \mathrm{m}^{2}$ and $60 \mathrm{~g} / \mathrm{m}^{2}$ treatments, while there was no significant difference in SGR between the $40 \mathrm{~g} / \mathrm{m}^{2}$ and $60 \mathrm{~g} / \mathrm{m}^{2}$ treatments.

\section{Growth rate of Phronima pacifica}

The results of growth rate of $P$. pacifica under the four C. lentillifera stock densities are presented in Figure 2. The highest growth rate of $P$. pacifica was observed under the $60 \mathrm{~g} / \mathrm{m}^{2}$ treatment at $4.41 \mathrm{ind} /$ day. Based on the ANOVA analysis of growth rates of $P$. pacifica, it showed that stocking density of $C$. lentillifera significantly influenced $P$. pacifica growth density $(\mathrm{P}<0.05)$.

\section{Population density of Phronima pacifica}

Phronima pacifica population density exhibited a sigmoid growth trend, and the results obtained after culturing under different $C$. lentillifera stocking densities for 40 days and recorded every 2 days are presented in Figure 3. The exponential phase represents the multiplication of individual as the result of reproduction. The exponential phase was on the $10^{\text {th }}$ day of observation, with the highest population being $61 \mathrm{ind} / \mathrm{L}$, followed by the stationary phase, which occurred on the $18^{\text {th }}$ day of observation with the highest population being 98 ind/L. The death phase fell under the $30^{\text {th }}$ day of observation with the highest population density being 28 ind/L.

This data relates to nutritional analysis because $P$. pacifica has the highest nutritional quality observed during exponential phase. Therefore, the nutritional analysis was conducted during exponential phase.

\section{The biomass of Phronima pacifica}

Phronima pacifica biomass results on a wet weight basis are presented in Figure 4. The highest weight of $P$. pacifica biomass during the study was in the treatment $\mathrm{D}$ $(1.14 \mathrm{~g})$ and the lowest was in treatment $\mathrm{A}(0.83 \mathrm{~g})$.

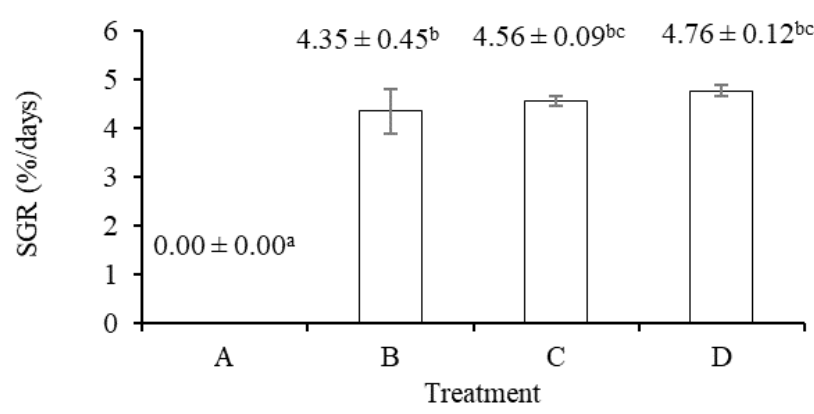

Figure 1. Specific growth rates of Caulerpa lentillifera under various stocking densities. A (Control): $0 \mathrm{~g} / \mathrm{m}^{2} ; \mathrm{B}: 20 \mathrm{~g} / \mathrm{m}^{2}$; C: 40 $\mathrm{g} / \mathrm{m}^{2} ; \mathrm{D}: 60 \mathrm{~g} / \mathrm{m}^{2}$. Different superscript letters indicate significant differences between treatments $(\mathrm{p}<0.05)$

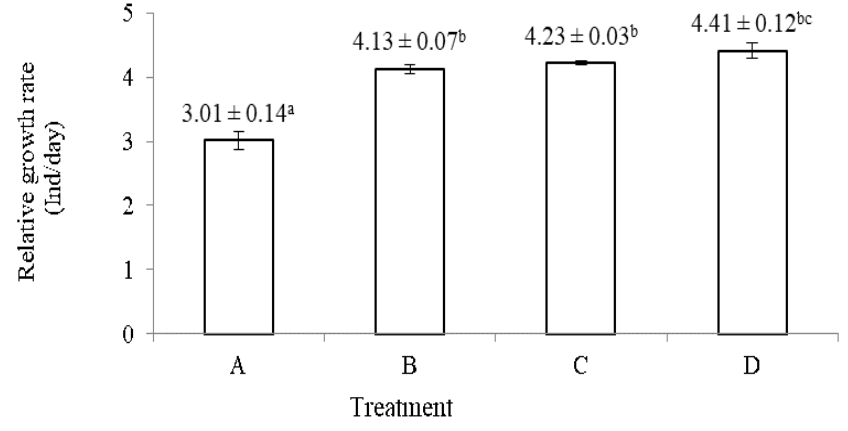

Figure 2. Relative growth rates of Phronima pacifica cultured under different Caulerpa lentillifera stocking densities. A (Control): $0 \mathrm{~g} / \mathrm{m}^{2}$; B: $20 \mathrm{~g} / \mathrm{m}^{2}$; C: $40 \mathrm{~g} / \mathrm{m}^{2}$; D: $60 \mathrm{~g} / \mathrm{m}^{2}$. Different superscript letters indicate significant differences between treatments $(\mathrm{p}<0.05)$

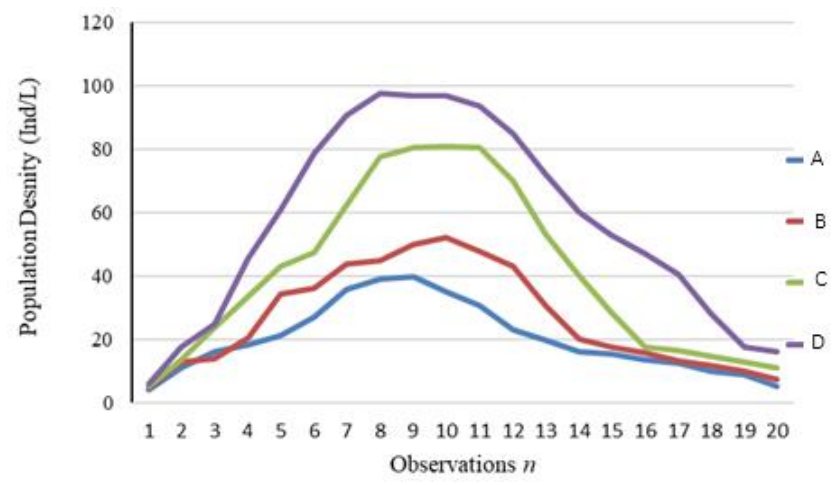

Figure 3. Trend of Phronima pacifica population density under varying Caulerpa lentillifera stocking densities for 40 days recorded every 2 days. A: $0 \mathrm{~g} / \mathrm{m}^{2} ; \mathrm{B}: 20 \mathrm{~g} / \mathrm{m}^{2} ; \mathrm{C}: 40 \mathrm{~g} / \mathrm{m}^{2}$; D: 60 $\mathrm{g} / \mathrm{m}^{2}$. Different superscript letters indicate significant differences between treatments $(p<0.05)$

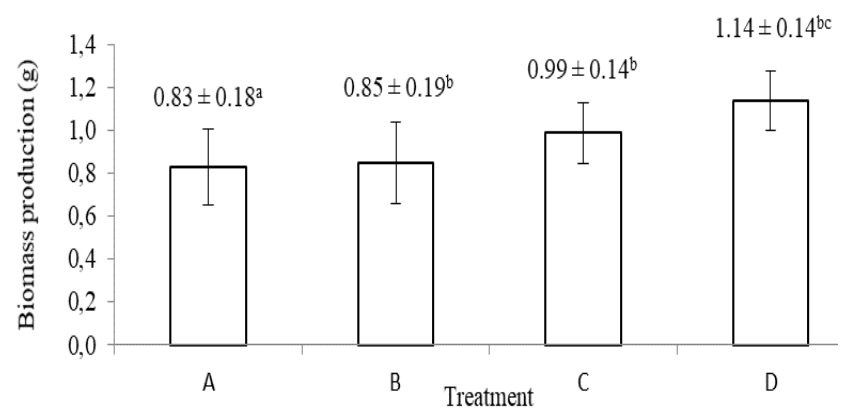

Figure 4. Phronima pacifica biomass under varying Caulerpa lentillifera stocking densities. A (Control): $0 \mathrm{~g} / \mathrm{m}^{2} \mathrm{~B}: 20 \mathrm{~g} / \mathrm{m}^{2} \mathrm{C}$ : $40 \mathrm{~g} / \mathrm{m}^{2}$ D: $60 \mathrm{~g} / \mathrm{m}^{2}$. Different superscript letters indicate significant differences between treatments $(p<0.05)$

Nutrient content in Phronima pacifica

The highest protein and fat contained in $P$. pacifica under different $C$. lentillifera stocking densities were produced by the $60 \mathrm{~g} / \mathrm{m}^{2}$ treatment with $60.23 \%$ and $10.24 \%$, respectively, while the lowest levels were $45.26 \%$ and $6.04 \%$, respectively, which were observed under the 0 $\mathrm{g} / \mathrm{m}^{2}$ treatment. The proximate analysis results are presented in Table 3. 
Phronima pacifica cultured under different $C$. lentillifera stocking densities had varying fatty acid types. Among the fatty acids contained in P. pacifica, EPA was the type of fatty acid that is most commonly found. EPA (C20: 5n-3) was the most commonly found fatty acid type. $P$. pacifica cultured under the treatment of $60-\mathrm{g} / \mathrm{m}^{2}$ stock density had the highest C20: $5 n-3(13.23 \% \pm 0.08 \%)$, while the lowest EPA (C20: 5 n-3) was observed in P. pacifica cultured under the $0 \mathrm{~g} / \mathrm{m}^{2}$ treatment $(6.19 \% \pm 0.08 \%)$. DHA (C22: 6n-3) levels contained under the treatment of $60-\mathrm{g} / \mathrm{m}^{2}$ stock density were the highest among other treatments $(6.07 \pm 0.03 \%)$, as well as the ARA content (C20: 4n-6) contained under the treatment of $60-\mathrm{g} / \mathrm{m}^{2}$ stock density was the highest $(8.23 \pm 0.07 \%)$. The results total fatty acid in $P$. pacifica under varying $C$. lentillifera stocking densities are presented in Table 4.

Lysine was the most common type of amino acid found under the treatment of $60-\mathrm{g} / \mathrm{m}^{2}$ C. lentillifera stocking density $(45.23 \% \pm 0.01 \%)$, followed by aspartic acid (37.94 $\pm 0.01 \%)$ and methionine $(32.40 \pm 0.07 \%)$. P. pacifica amino acid profiles under varying $C$. lentillifera stocking densities are presented in Table 5.

\section{Discussion}

This study found that the addition of sea grape $(C$. lentillifera) into cultured media significantly enhanced the growth of $P$. pacifica. Caulerpa spp. is native to warm tropical waters and is relatively easy to propagate. Several factors influence Caulerpa spp. growth, including salinity, temperature, nutrient availability and light (Mosquera and Salamanca 2016). According to Darmawati (2015), the population density of $P$. pacifica increased with an increase in stocking density. Similarly, in the present study, the highest $P$. pacifica growth rate was observed under the highest $C$. lentillifera stocking density $\left(60 \mathrm{~g} / \mathrm{m}^{2}\right)$. This is because $P$. pacifica not only feeds on algae but also detritus. Consequently, since $C$. lentillifera is an alga in which the entire plant structure is a thallus, the dead thallus would also become detritus, which also provides nutrients for P. pacifica.

Table 2. Population density of Phronima pacifica in each stage under varying Caulerpa lentillifera stocking densities

\begin{tabular}{lcccc}
\hline \multirow{2}{*}{ Growth phase } & \multicolumn{4}{c}{ Population density (ind/L) } \\
\cline { 2 - 5 } & Treatment A & Treatment B & Treatment C & Treatment D \\
\hline Lag & $21 \pm 0.25^{\mathrm{a}}$ & $24 \pm 0.36^{\mathrm{a}}$ & $30 \pm 0.18^{\mathrm{b}}$ & $40 \pm 0.08^{\mathrm{b}}$ \\
Exponential & $28 \pm 0.09^{\mathrm{a}}$ & $35 \pm 0.78^{\mathrm{b}}$ & $60 \pm 0.68^{\mathrm{b}}$ & $75 \pm 0.04^{\mathrm{b}}$ \\
Stationary & $39 \pm 0.25^{\mathrm{a}}$ & $55 \pm 0.09^{\mathrm{b}}$ & $80 \pm 0.48^{\mathrm{b}}$ & $98 \pm 0.96^{\mathrm{b}}$ \\
Death & $19 \pm 0.19^{\mathrm{a}}$ & $20 \pm 0.08^{\mathrm{a}}$ & $18 \pm 0.45^{\mathrm{a}}$ & $19 \pm 0.98^{\mathrm{a}}$ \\
\hline
\end{tabular}

Notes: Treatment A (C. lentillifera $\left.0 \mathrm{~g} / \mathrm{m}^{2}\right)$; B $\left(\right.$ C. lentillifera $\left.20 \mathrm{~g} / \mathrm{m}^{2}\right) ; \mathrm{C}\left(\right.$ C. lentillifera $\left.40 \mathrm{~g} / \mathrm{m}^{2}\right) ; \mathrm{D}\left(\right.$ C. lentillifera $\left.60 \mathrm{~g} / \mathrm{m}^{2}\right)$. Different superscript letters indicate significant differences between treatments $(\mathrm{p}<0.05)$

Table 3. Proximate analysis results for Phronima pacifica under varying Caulerpa lentillifera stocking densities

\begin{tabular}{cccccc}
\hline \multirow{2}{*}{ Treatments } & \multicolumn{5}{c}{ Dry weight content percentage } \\
\cline { 2 - 6 } & Protein (\%) & Carbohydrate (\%) & Crude fat (\%) & Ash (\%) & Crude fiber (\%) \\
\hline A & $45.26 \pm 0.03^{\mathrm{a}}$ & $18.80 \pm 0.02$ & $6.04 \pm 0.04^{\mathrm{a}}$ & $24.27 \pm 0.07$ & $5.63 \pm 0.06$ \\
B & $52.90 \pm 0.04^{\mathrm{b}}$ & $17.72 \pm 0.03$ & $6.24 \pm 0.03^{\mathrm{a}}$ & $17.69 \pm 0.03$ & $5.45 \pm 0.08$ \\
C & $55.45 \pm 0.02^{\mathrm{b}}$ & $17.57 \pm 0.05$ & $8.57 \pm 0.02^{\mathrm{b}}$ & $15.63 \pm 0.03$ & $3.78 \pm 0.03$ \\
D & $60.23 \pm 0.01^{\mathrm{c}}$ & $15.22 \pm 0.03$ & $10.24 \pm 0.03^{\mathrm{c}}$ & $11.86 \pm 0.03$ & $2.45 \pm 0.08$ \\
\hline
\end{tabular}

Notes: Treatment A (C. lentillifera $\left.0 \mathrm{~g} / \mathrm{m}^{2}\right) ; \mathrm{B}\left(\right.$ C. lentillifera $\left.20 \mathrm{~g} / \mathrm{m}^{2}\right) ; \mathrm{C}\left(\right.$ C. lentillifera $\left.40 \mathrm{~g} / \mathrm{m}^{2}\right) ; \mathrm{D}\left(\right.$ C. lentillifera $\left.60 \mathrm{~g} / \mathrm{m}^{2}\right)$. Different superscript letters indicate significant differences between treatments $(\mathrm{p}<0.05)$

Table 4. Total fatty acid in Phronima pacifica under varying Caulerpa lentillifera stocking densities

\begin{tabular}{|c|c|c|c|c|}
\hline \multirow{2}{*}{ Fatty acid profile (\%) } & \multicolumn{4}{|c|}{ Treatment of $C$. lentillifera stocking density } \\
\hline & A $\left(0 \mathrm{~g} / \mathrm{m}^{2}\right)$ & B $\left(20 \mathrm{~g} / \mathrm{m}^{2}\right)$ & $\mathrm{C}\left(40 \mathrm{~g} / \mathrm{m}^{2}\right)$ & $D\left(60 \mathrm{~g} / \mathrm{m}^{2}\right)$ \\
\hline C14:0 & $9.52 \pm 0.09^{b}$ & $10.49 \pm 0.06^{c}$ & $5.41 \pm 0.02^{\mathrm{a}}$ & $5.48 \pm 0.09^{\mathrm{a}}$ \\
\hline $\mathrm{C} 15: 0$ & $6.09 \pm 0.08^{\mathrm{a}}$ & $7.18 \pm 0.03^{\mathrm{c}}$ & $6.17 \pm 0.04^{b}$ & $6.15 \pm 0.08^{\mathrm{b}}$ \\
\hline $\mathrm{C} 16: 0$ & $5.14 \pm 0.07^{\mathrm{a}}$ & $6.29 \pm 0.09^{b}$ & $7.97 \pm 0.08^{c}$ & $8.59 \pm 0.04^{\mathrm{d}}$ \\
\hline C18:0 & $2.71 \pm 0.05^{\mathrm{a}}$ & $6.65 \pm 0.01^{\mathrm{d}}$ & $5.52 \pm 0.03^{c}$ & $4.91 \pm 0.09^{b}$ \\
\hline C18:1 n-9 & $3.07 \pm 0.03^{\mathrm{a}}$ & $4.95 \pm 0.03^{\mathrm{b}}$ & $4.89 \pm 0.08^{b}$ & $6.61 \pm 0.01^{\mathrm{c}}$ \\
\hline$C 18: 2 n-6$ & $4.83 \pm 0.09^{\mathrm{a}}$ & $5.46 \pm 0.07^{\mathrm{b}}$ & $6.49 \pm 0.07^{c}$ & $8.07 \pm 0.02^{\mathrm{d}}$ \\
\hline C18:3n-3 & $3.54 \pm 0.02^{\mathrm{a}}$ & $4.76 \pm 0.08^{\mathrm{b}}$ & $4.89 \pm 0.03^{c}$ & $7.32 \pm 0.01^{\mathrm{d}}$ \\
\hline C20:2 & $2.30 \pm 0.04^{\mathrm{a}}$ & $2.83 \pm 0.02^{\mathrm{b}}$ & $6.02 \pm 0.04^{c}$ & $3.05 \pm 0.03^{\mathrm{d}}$ \\
\hline C20:4 n-6 & $2.71 \pm 0.03^{\mathrm{a}}$ & $4.15 \pm 0.03^{b}$ & $6.15 \pm 0.09^{c}$ & $8.23 \pm 0.07^{d}$ \\
\hline$C 20: 5 n-3$ & $6.19 \pm 0.08^{a}$ & $9.64 \pm 0.07^{b}$ & $10.88 \pm 0.02^{c}$ & $13.23 \pm 0.08^{d}$ \\
\hline$C 22: 6 n-3$ & $2.23 \pm 0.05^{\mathrm{a}}$ & $3.08 \pm 0.04^{\mathrm{b}}$ & $5.07 \pm 0.01^{\mathrm{c}}$ & $6.07 \pm 0.03^{\mathrm{d}}$ \\
\hline
\end{tabular}

Notes: Different superscript letter indicates significant difference between treatments $(\mathrm{p}<0.05)$ 
Table 5. Total amino acid profiles of Phronima pacifica under varying Caulerpa lentillifera stocking densities

\begin{tabular}{|c|c|c|c|c|}
\hline \multirow{2}{*}{ Amino acid (\%) } & \multicolumn{4}{|c|}{ Treatment of $C$. lentillifera stocking density } \\
\hline & $A\left(0 \mathrm{~g} / \mathrm{m}^{2}\right)$ & B $\left(20 \mathrm{~g} / \mathrm{m}^{2}\right)$ & $\mathrm{C}\left(40 \mathrm{~g} / \mathrm{m}^{2}\right)$ & $D\left(60 \mathrm{~g} / \mathrm{m}^{2}\right)$ \\
\hline L-aspartic acid & $18.92 \pm 0.05^{\mathrm{a}}$ & $27.85 \pm 0.07^{b}$ & $29.52 \pm 0.09^{c}$ & $37.94 \pm 0.01^{d}$ \\
\hline L-serine & $15.61 \pm 0.02^{\mathrm{b}}$ & $14.76 \pm 0.03^{\mathrm{a}}$ & $17.63 \pm 0.08^{c}$ & $17.62 \pm 0.03^{c}$ \\
\hline L-glutamic acid & $16.61 \pm 0.02^{\mathrm{a}}$ & $27.36 \pm 0.02^{\mathrm{c}}$ & $24.35 \pm 0.02^{\mathrm{b}}$ & $30.37 \pm 0.07^{d}$ \\
\hline Glycine & $19.36 \pm 0.06^{\mathrm{d}}$ & $17.33 \pm 0.01^{\mathrm{a}}$ & $18.78 \pm 0.07^{b}$ & $19.19 \pm 0.01^{\mathrm{c}}$ \\
\hline L-histidine & $6.78 \pm 0.02^{\mathrm{a}}$ & $8.25 \pm 0.01^{\mathrm{b}}$ & $13.50 \pm 0.05^{\mathrm{c}}$ & $20.70 \pm 0.09^{d}$ \\
\hline L-arginine & $10.51 \pm 0.01^{\mathrm{a}}$ & $15.85 \pm 0.05^{\mathrm{b}}$ & $21.89 \pm 0.08^{c}$ & $27.28 \pm 0.08^{d}$ \\
\hline L-threonine & $15.02 \pm 0.09^{\mathrm{a}}$ & $18.47 \pm 0.06^{\mathrm{b}}$ & $20.16 \pm 0.03^{c}$ & $20.37 \pm 0.06^{\mathrm{d}}$ \\
\hline L-alanine & $10.65 \pm 0.03^{\mathrm{a}}$ & $12.51 \pm 0.08^{b}$ & $13.98 \pm 0.01^{\mathrm{c}}$ & $15.51 \pm 0.04^{\mathrm{d}}$ \\
\hline L-proline & $15.25 \pm 0.09^{\mathrm{a}}$ & $18.08 \pm 0.07^{c}$ & $17.44 \pm 0.04^{b}$ & $19.00 \pm 0.09^{d}$ \\
\hline L-valine & $20.24 \pm 0.09^{a}$ & $25.72 \pm 0.05^{b}$ & $28.13 \pm 0.07^{c}$ & $28.87 \pm 0.03^{\mathrm{d}}$ \\
\hline L-methionine & $11.10 \pm 0.02^{\mathrm{a}}$ & $15.89 \pm 0.09^{b}$ & $24.40 \pm 0.05^{\mathrm{c}}$ & $32.40 \pm 0.07^{\mathrm{d}}$ \\
\hline L-Lysine $\mathrm{HCl}$ & $21.57 \pm 0.07^{a}$ & $27.59 \pm 0.03^{b}$ & $35.99 \pm 0.02^{c}$ & $45.23 \pm 0.01^{\mathrm{d}}$ \\
\hline L-isoleucine & $19.97 \pm 0.01^{\mathrm{b}}$ & $18.87 \pm 0.02^{\mathrm{a}}$ & $21.50 \pm 0.07^{c}$ & $22.99 \pm 0.04^{\mathrm{d}}$ \\
\hline L-leucine & $22.44 \pm 0.05^{\mathrm{a}}$ & $22.97 \pm 0.02^{b}$ & $25.46 \pm 0.09^{c}$ & $30.88 \pm 0.05^{\mathrm{d}}$ \\
\hline L-phenylalanine & $15.49 \pm 0.07^{b}$ & $14.41 \pm 0.07^{\mathrm{a}}$ & $15.97 \pm 0.05^{\mathrm{c}}$ & $16.98 \pm 0.10^{\mathrm{d}}$ \\
\hline
\end{tabular}

Note: Different superscript letters indicate significant differences between treatments $(\mathrm{p}<0.05)$

Phronima pacifica growth rate is influenced by individual density from the initial growth phase until the peak phase. According to Punnarak et al. (2017), differences in growth rate in Phronima sp. are due to several factors. In addition, Preciado et al. (2017) report that Phronima spp. are detritus eaters and some species are algae gazers, so that the higher the seaweed stocking density, the greater the growth rate of Phronima sp. Growth begins with a lag phase or an adaptation phase followed by the exponential phase, declining phase, stationary phase, and eventually the death phase.

The sigmoid curve observed in the present study was formed by the growth trends in the adaptation phase, exponential phase, stationary phase and until death phase. Lag phase is the initial growth phase where the growth rate of $P$. pacifica is still low. $P$. pacifica abundance is influenced by detritus availability in a culture container and conducive environmental conditions. The growth of $P$. pacifica individuals cultured using $C$. lentillifera under different stocking densities exhibited significantly different trends in lag phase $(\mathrm{P}>0.01)$. The growth trends of $P$. pacifica during maintenance exhibits a sigmoid curve. The adaptation phase begins from 4-6 days of observation in each treatment, with the highest density being $25 \mathrm{ind} / \mathrm{L}$, which was observed due to the preparation of the environment and adjustment to the organic matter concentrations in the $C$. lentillifera culture media, so that there was no considerable population growth. P. pacifica adapts much more rapidly to the new environment if the density of the culture media is similar to the density under natural conditions, so that growth would take longer under conditions where there is a difference between the concentrations of the culture media and in nature. Herawati et al. (2017) reported that differences in concentrations between culture media and cells in plankton will have an effect on the restitution of enzymes and concentrates to further levels of growth and the presence of nutrients in cells through the diffusion process as a result of differences concentration between culture media and body fluids. In addition, differences in $P$. pacifica population density could be due to differences in seaweed distribution, which would lead to differences in available nutrients in the culture media and detritus abundance under varying seaweed distribution. Furthermore, the amount of detritus, which is an organic food source for $P$. pacifica, a filter feeder, would vary under varying seaweed distribution.

In the exponential phase, the nutrient concentrations in $P$. pacifica are the highest, growth has not been maximized, and the number of $P$. pacifica individuals begins to increase. Based on research conducted by Fogg (1965) and Herawati et al. (2014), the exponential phase is the phase where the nutrient concentrations and plankton density have not reached peak periods. However, in the present study, feeding was carried out in the exponential plankton phase. The exponential phase is the phase with the nutrient concentrations in Phronima spp. was the highest, although growth had not been maximized. The exponential phase in the present study was observed on day $10^{\text {th }}$ and the results are consistent with the findings of Darmawan (2014) in which $P$. pacifica population was in the exponential growth phase at 9 and 10 days. In all treatments in the present study, the exponential phase was observed at 4 days. The rate of $P$. pacifica population growth depends on the capacity of $P$. pacifica to produce seeds. According to Moosa and Aswandy (1984) and Fattah et al. (2014), the number of eggs produced by Amphipoda species varies greatly, and is influenced by several factors, including the type, age, weight, and size of the species, so that there is a correlation between the size and number of $P$. pacifica produced. The greater the size of the $P$. pacifica, the more eggs it will produce. Eggs produced by $P$. pacifica hatch range from 50\%-75\% (Aoki et al. 2013).

The stationary phase is a phase that occurs after the exponential phase, and is characterized by the lack of growth, or a decrease in the amount of relatively the same. The stationary phase generally represents a peak in population growth until a drastic decrease in the population due to mass death (Darmawan 2014; Herawati et al. 2015). The stationary phase was observed at 18 days with the highest population being $98 \mathrm{ind} / \mathrm{L}$ in the $60 \mathrm{~g} / \mathrm{m}^{2}$ treatment, 
which was thought to be caused by abundant nutrient detritus in the culture media. Moore and Eastman (2015) stated that seaweed with good nutrition will have a lot of thalli, and the thallus of dead seaweed will form detritus which serves as a food source for other organisms such as zooplankton, especially $P$. pacifica.

The death phase could be caused by several factors, including high temperature, poor nutrient availability in water, poor $\mathrm{pH}$ conditions, contamination and decreased photosynthesis. Herawati et al. (2017) reported that contamination could decrease population density and decrease photosynthesis. A decrease in nutrient availability would lead to the death of bacteria. In addition, toxic conditions created by the death of algae would also adversely affect growth. In the final phase of $P$. pacifica culture, the population increase, which could have been caused by a reduction in the number of nutrients in the culture media (Jiménez et al. 2014).

The greatest increase in $P$. pacifica biomass was achieved in the $60 \mathrm{~g} / \mathrm{m}^{2}$ treatment with $1.14 \mathrm{~g}$. The biomass reported in the present study is higher than that reported by Herawati et al. (2020), where the biomass of Phronima sp. was $0.51 \mathrm{~g}$ after 30 days of culture. The high biomass of $P$. pacifica cultured using $C$. lentillifera was because of the high growth rate and high nutrient content of $C$. lentillifera. According to Bishop and Geiger (2006), differences in population density at harvesting is closely associated with the nutritional content of the feed provided. In addition to the nutrient concentrations in culture media, environmental conditions influence the growth and biomass of $P$. pacifica. In Darmawan (2014), plankton growth trends were influenced by factors such as physical water conditions, type of feed and feed concentrations. Under optimal water quality and maximum feed availability consistent with the growth requirements of $P$. pacifica, the maximum growth rate would be achieved quite rapidly and with more population peaks. Water quality, which is one of the key environmental factors influencing $P$. pacifica growth and development, could be maintained during the rearing period through daily water quality measurements in-situ.

In the present study, the highest protein and fat nutritional quality were observed under the $60 \mathrm{~g} / \mathrm{m}^{2}$ treatment with $60.23 \%$ and $10.24 \%$, respectively, while the lowest was observed in the $0 \mathrm{~g} / \mathrm{m}^{2}$ treatment with $45.26 \%$ and $6.04 \%$, respectively. The nutritional quality results reported in the present study are higher than those reported in Herawati et al. (2020), where the highest protein and fat contents under $P$. pacifica mass culture using organic waste fermented using probiotic bacteria were $58.90 \%$ and $8.24 \%$, respectively, while the lowest was $41.26 \%$ and $5.04 \%$, respectively. The high protein and low-fat content in the present study were caused by high nutrient and detritus amounts present in the culture media as feed. Widianingsih et al. (2008) reported that the higher the nitrogen and phosphorus contents, the higher the protein in the culture media, while fat content is inversely proportional to protein content. The results of the study are consistent with the findings of Lim et al. (2011), where protein content was always inversely proportional to fat content.
The results of the present study are reinforced by of the findings of Zengin et al. (2013), Monroig et al. (2013), and Tocher (2015), when PUFA is a key nutrient required for the formation of long-chain PUFA, which, in turn, form EPA and 351 docosahexaenoic acids (DHA) depending on the species.

Phronima pacifica is one of the natural feeds given to shrimp to substitute Artemia spp. especially in the postlarval stage due to the high nutritional contents. During this stage, Artemia sp. is deficient or low in natural feed for EPA and DHA contents. Therefore, $P$. pacifica can be used as a substitute. Akbary et al. (2011) and Ali et al. (2017) reported that Artemia sp. used as natural feed for shrimp contain relatively low EPA and DHA contents, specifically its stadia post larvae, so that enrichment is required.

According to the results of the present study, the highest amino acid contents were observed in the $60 \mathrm{~g} / \mathrm{m}^{2}$ treatment with the highest lysine contents of $45.23 \%$. Conversely, the lowest amino acid contents were observed in the $0 \mathrm{~g} / \mathrm{m}^{2}$ treatment with $21.57 \%$. The amino acid contents observed in the present study are slightly higher than those observed by Herawati et al. (2020) (i.e. 44.16\%) that used organic waste fermented with probiotic bacteria. According to Ovie and Ovie (2006), Valverde et al. (2013) and Herawati et al. (2015), lysine forms the structural framework of vitamin B1, has antiviral effects, facilitates the absorption of calcium, enhances appetite, and facilitates the production of carnitine that enhances the conversion of fatty acids into energy. The high lysine contents in $P$. pacifica used as natural feed could increase growth. In addition, it is a key ingredient in blood antibodies, strengthens the circulatory system and improves cells, while lysine deficiency can cause fin erosion and fish death (Nafisi et al. 2018).

In conclusion, the present study investigated the influence of varying stocking densities of $C$. lentillifera added into culture media on the growth, biomass and nutrition profiles of $P$. pacifica. Based on the results of the study, both $40 \mathrm{~g} / \mathrm{m}^{2}$ and $60 \mathrm{~g} / \mathrm{m}^{2}$ treatment resulted in high $P$. pacifica growth and biomass production. However, the highest nutritional quality based on proximate analysis, and fatty acid and amino acids profile analyses, were observed in $P$. pacifica mass-cultured under $60 \mathrm{~g} / \mathrm{m}^{2}$ treatment. The application of the optimal stocking density of $C$. lentillifera into $P$. pacifica culture media determined in the present study could increase the nutritional quality of $P$. pacifica, a natural fish feed, which in turn could enhance aquaculture productivity.

\section{ACKNOWLEDGEMENTS}

This research was funded by the Directorate of Research and Community Service, Directorate General of Strengthening for Development Research, The Ministry of Research, Technology and Higher Education of The Republic of Indonesia, fiscal year of 2020. 


\section{REFERENCES}

Akbary P, Hosseini SA, Imanpoor MR. 2011. Enrichment of Artemia nauplii with essential fatty acids and vitamin $\mathrm{C}$ : Effect on rainbow trout (Oncorhynchus mykiss) larvae performance. Iranian J Fish Sci 10 (4): 557-569.

Ali A, Mozanzadeh MT, Agh N, Bahabadi MN. 2017. Effects of enriched artemia with Saccharomyces cerevisiae and Chaetoceros gracilis on growth performance, stress resistance and fatty acid profile of Litopenaeus vannamei postlarvae. J Fish Aquat Stud 5 (2): 669-673.

AOAC. 2005. Official Methods of Analysis. $18^{\text {th }}$ ed. Association of Official Analytical Chemist, Arlington, V.A.

Aoki MK, Matsumoto-Ohsima C, Hirose E, Nishikawa J. 2013. Motheryoung cohabitation in Phronimella elongate and Phronima spp. (Amphipoda, Hyperiidea, Phronimidae). J Mar Biol Assoc U.K. 93 (6): $1553-1556$.

Azizah R. 2006. Experimentation of various methods of latoh cultivation (Caulerpa racemosa) as an effort to support production continuity. Mar Sci 11 (2): 101-105.

Baeza-Rojano E, Calero-Cano S, Hachero-Cruzado I, Guerra-García JM 2013. A preliminary study of the Caprella scaura amphipod culture for potential use in aquaculture. J Sea Res 83: 146-151. DOI: 10.1016/j.seares.2013.04.014.

Bishop R, Geiger S. 2006. Phronima energetics: Is there a bonus to the barrel. Crustaceana 79 (9): 1059-1070.

Damle DK, Chari MS. 2011. Performance evaluation of different anima wastes on culture of Daphnia sp. J Fish Aquat Sci 6 (1): 57-61. DOI: $10.3923 /$ jfas.2011.57.61

Darmawan J. 2014. Population growth of Daphnia sp. on aquaculture media with addition of wastewater to dumbo catfish cultivation (Clarias gariepinus Burchell, 1822). Biol Bull 13 (1): 57-63.

Darmawati D. 2015. Optimization of seedling spacing on Caulerpa sp growth in Laguruda Waters, Takalar Regency. Octopus J Fish Sci 4 (1): 337-344.

Elder LE, Seibel BA. 2015. The thermal stress response to diel vertical migration in the hyperiid amphipod Phronima sedentaria. Comp Biochem Physiol Part A: Mol Integr Physiol 187: 20-26. DOI: 10.1016/j.cbpa.2015.04.008.

Fattah MH, Saenong M, Asbar, Busaeri SR. 2014. Production of endemic microcrustacean (Phronima sp.) to substitute Artemia salina in tige prawn cultivation. J Aquac Res Dev 5 (5): 1-5.

Fattah MH, Busaeri SR, Munandar A. 2019. Survival rate and quality of Phronima suppa (Phronima sp) zoea with the cryptobiosis application. IOP Conf Ser Earth Environ Sci 391 (1): 012076. DOI: 10.1088/1755-1315/391/1/012076

Fogg GE. 1965. Algae Culture and Phytoplankton Ecology. The University of Wisconsin Press, USA.

Herawati VE, Hutabarat J, Radjasa OK. 2014. Nutritional content of Artemia sp. fed with Chaetoceros calcitrans and Skeletonema costatum. Hayati J Biosci 21 (4): 166-172. DOI: 10.4308/hjb.21.4.166

Herawati VE, Hutabarat J, Radjasa OK. 2015. Growth and survival rate of tilapia (Oreochromis niloticus) larvae fed by Daphnia magna cultured with organic fertilizer resulted from probiotic bacteria fermentation. Hayati J Biosci 22 (4): 169-173. DOI: 10.1016/j.hjb.2015.08.001

Herawati VE, Nugroho RA, Pinandoyo, Darmanto YS, Hutabarat J. 2017 Nutritional value content, biomass production and growth performance of Daphnia magna cultured with different animal wastes resulted from probiotic bacteria fermentation. IOP Conf Ser Earth Environ Sci 55 (1): 012004. DOI: 10.1088/1755-1315/55/1/012004.

Herawati VE, Nugroho RA, Pinandoyo, Darmanto YS, Hutabarat J. 2018 The effect of fermentation time with probiotic bacteria on organic fertilizer as Daphnia magna cultured medium towards nutrient quality, biomass production and growth performances enhancement. IOP Conf Ser Earth Environ Sci 116 (1): 012089. DOI: 10.1088/1755-1315/116/1/012089.

Herawati VE, Pinandoyo P, Rismaningsih N, Darmanto D, Hutabarat J, Radjasa OK. 2020. The effect of probiotic bacteria in culture media using organic fertilizer for population density, biomass production and nutrient quality of Phronima sp. as natural feed. Aquac Res 51 (2): 836-843.

Jiménez-Prada P, Hachero-Cruzado I, Giráldez I, Fernández-Diaz C, Vilas C, Cañavate JP, Guerra-García JM. 2018. Crustacean amphipods from marsh ponds: A nutritious feed resource with potential for application in integrated multi-trophic aquaculture. PeerJ 6: e4194. DOI: $10.7717 /$ peerj. 4194

Krebs CJ. 1972. The Experimental Analysis of Distribution and Abundance. Ecology. Harper and Row, New York.

Lim CM, Aksoy Y, Klesius P. 2011. Lipid and fatty acid requirements of tilapia, North America. Indon J Aquat Sci Fish 73: 188-193. DOI: 10.1080/15222055.2011.579032.

Lowry JK, Myers AA. 2017. A phylogeny and classification of the Amphipoda with the establishment of the new order Ingolfiellida (Crustacea: Peracarida). Zootaxa 4265 (1): 1-89.

Monroig Ó, Tocher DR, Navarro JC. 2013. Biosynthesis of polyunsaturated fatty acids in marine invertebrates: Recent advances in molecular mechanisms. Mar Drugs 11 (10): 3998-4018. DOI: 10.3390/md11103998.

Moore PG, Eastman LB. 2015. The tube-dwelling lifestyle in crustaceans and its relation to feeding. Nat His Crustacea 2: 35-77.

Moosa MK, Aswandy I. 1984. Reef shrimp (Panulirus spp.) from Indonesian Fisheries [Udang Karang (Panulirus spp.) dari Perikanan Indonesia]. LON-LIPI, Jakarta. [Indonesian]

Mosquera-Murillo Z, Peña-Salamanca EJ. 2016. Effect of salinity on growth of the green alga Caulerpa sertularioides (Bryopsidales, Chlorophyta) under laboratory conditions. Hidrobiológica 26 (2): 277-282.

Nafisi BM, Torfi MM, Agh N, Ahmadi A, Yaghoubi M. 2018. Enriched artemia with L-lysine and DL-methionine on growth performance, stress resistance, and fatty acid profile of Litopenaeus vannamei postlarvae. J Appl Aquac 30 (4): 325-336.

Ovie SI, Ovie SO. 2006. Moisture, protein, and amino acid contents of three freshwater zooplankton used as feed for aquacultured larvae and postlarvae. J Fish Aquat Sci 58 (1): 94-100.

Parker AN, Maria AM. 2015. Native and adventive detritivores (Diplopoda, Isopoda and Amphipoda) in a modified landscape: influence of forest type and edge. N Z J Ecol 39 (2): 323-331.

Preciado I, Cartes JE, Punzón A, Frutos I, López-López L, Serrano A. 2017. Food web functioning of the benthopelagic community in a deep-sea seamount based on diet and stable isotope analyses. DeepSea Res Part II: Topical Stud Oceanogr 137: 56-68. DOI: 10.1016/j.dsr2.2016.07.013.

Punnarak P, Jarayabhand P, Piumsomboon A. 2017. Cultivation of harpacticoid copepods (Families Harpacticidae and Laophontidae) under selected environmental conditions. Agric Nat Resour 51 (4): 278-285.

Rojano EB, Cruzado IH, Garcia JMG. 2014. Nutritional analysis of freshwater and marine amphipods from the strait of Gibraltar and potential aquaculture applications. J Sea Res 85: 29-36.

Sulistijo MS. 2002. Seaweed Cultivation Research (Macroalgae/ Seaweed) in Indonesia. Center for Research in Indonesian Oceanography, Jakarta, Indonesia.

Tocher DR. 2015. Omega-3 long-chain polyunsaturated fatty acids and aquaculture in perspective. Aquaculture 449: 94-107. DOI: 10.1016/j.aquaculture.2015.01.010

Valverde JC, Martínez-Llorens S, Vidal AT, Jover M, Rodríguez C, Estefanell J, Gairín JI, Domingues PM, Rodríguez CJ, García BG. 2013. Amino acids composition and protein quality evaluation of marine species and meals for feed formulations in cephalopods. Aquac Intl 21 (2): 413-433.

Widianingsih, Ridho A, Hartati R, Harmoko. 2008. Nutrient content of spirulina platensis cultivated in different media. J Mar Sci 13 (3): 167-170.

Zengin H, Vural N, Çelik V. 2013. Comparison of changes in fatty acid composition of starved and fed rainbow trout, (Oncorhynchus mykiss) larvae. Turkish J Fish Aquat Sci 13 (3): 397-405. DOI: 10.4194/13032712-v13_3_02. 